\title{
MOC NIEOBECNOŚCI⒈
} JANOWI BERDYSZAKOWI (1934-2014) - IN MEMORIAM

Ostatnie pożegnanie Jana Berdyszaka na poznańskim Cmentarzu Miłostowo, nadzwyczajnie tłumne i, by tak rzec, wielopokoleniowe, uwiarygodniło treść nekrologu firmowanego przez Senat, pedagogów, pracowników i studentów Uniwersytetu Artystycznego w Poznaniu. Podczas wzruszającej ceremonii, konwencjonalne formuły nabrały głębokiego i osobistego znaczenia. Pogrążeni w smutku byliśmy świadomi, że żegnamy nie tylko wybitnego twórcę, lecz także, jak napisano, Niezwykłego Człowieka, „wspaniałego i niezastąpionego pedagoga. [...] Wychowawcę i przyjaciela wielu pokoleń artystów". Z rozmów, jakie wiedliśmy już po jej zakończeniu, wynikało niezbicie, że niejeden $\mathrm{z}$ nas sporo Mu zawdzięcza, a dla wielu spotkanie Profesora stało się prawdziwym przełomem.

Pamiętam swój pierwszy kontakt z Janem Berdyszakiem na korytarzu uczelni, bez mała trzydzieści lat temu. Spytana o zainteresowania naukowe, opowiedziałam o swej fascynacji sztuką niezależną lat 80., a zwłaszcza ujawniającą się w niej, na niespotykaną wcześniej skalę, rolą ikonografii religijnej. Ówczesny prorektor wysłuchał mej relacji życzliwie, lecz raczej bez entuzjazmu. W komentarzu wskazywał na sztukę tworzoną ponad religijnymi podziałami, choć wyrastającą $z$ tego samego pnia naszej duchowej egzystencji, co wiara religijna, i zanurzoną w strumieniu tej samej duchowej energii. Namawiał, by się nią głębiej zainteresować, sugerując możliwość

${ }^{1}$ Tytuł tekstu jest zarazem tytułem jednego z obrazów Jana Berdyszaka z cyklu Miejsca rezerwowane, o którym wspominam w dalszej części. 
dalszych rozmów na jej temat. Ziarno zostało wprawdzie rzucone, lecz by zakiełkowało, musiało upłynąć... ćwierć wieku. Pokłosiem stały się studia nad abstrakcją, nad jej „aromatem duchowym”2, a co za tym idzie - kilka tekstów, w tym również o artystycznym dorobku Profesora, ujętym z perspektywy skondensowanych w nim sensów i wartości spirytualnych. Choć bowiem zainteresowania twórcze Jana Berdyszaka były rozległe, to niejedna z jego prac, ba, nawet całe ich cykle, stanowią pochodną rozmyślań nad nadprzyrodzoną tajemnicą bytu i jej wyrazem plastycznym. Artysta stawiał też wielokrotnie pytanie o sens i możliwość prezentacji Boga, który jest czystym Byciem i odznacza się radykalną transcendencją, w sztuce. Odpowiedź, jakiej udzielał w swych tekstach i twórczości artystycznej, była przecząca. Pozostawała bowiem $\mathrm{W}$ związku $\mathrm{z}$ apofatycznymi nurtami teologiczno-metafizycznej medytacji nad Absolutem, kładącymi nacisk na jego niepoznawalność, a w konsekwencji prowadzącymi do negacji wizerunku. Apofatycznie (lecz w żadnym razie nie ateistycznie!) motywowany ikonoklazm Berdyszaka, przejawiający się w konsekwentnie abstrakcyjnym charakterze jego twórczości, wywodził się więc nie tylko z tradycji dwudziestowiecznej awangardy, z poetyki i estetyki artystycznego minimalizmu, lecz także z zainteresowań platonizmem i nurtami neoplatońskimi, mistyką żydowską, duchowością i sztuką Dalekiego Wschodu, a także duchową i artystyczną spuścizną chrześcijaństwa. Niektóre z prac naszego twórcy zainspirowało ensō - symbol buddyzmu zen, okrąg napisany jednym pociągnięciem pędzla; inne ascetyczne japońskie wnętrza i świątynie ogrodowe; jeszcze następne pustka Świętej Przestrzeni w judaizmie. Wiele kolejnych tkwi korzeniami w religii chrześcijańskiej, w jej nurcie apofatycznym, zwłaszcza w doświadczeniach mistyków, takich jak Mistrz Eckhart, św. Jan od Krzyż czy św. Teresa z Àvila. Jakkolwiek bowiem dogmat o Bożym Wcieleniu i jeszcze inne ważkie racje osłabiają $\mathrm{w}$ niej rangę postawy stosującej w poznaniu Boga metodę negacji, antynomii i paradoksu, to przecież miała ona niebagatelny wpływ na racjonalizację liturgii i refleksji teologicznej, na interpretowanie nauki Ojców Kościoła, rozwijając się w dialektyczną metodę mistycznej kontemplacji Boga, który jest ponad wszelkim bytem ${ }^{3}$. Warto przyjrzeć się tej właśnie grupie prac, a to z powodu ich wyjątkowości. Jakkolwiek bowiem wśród współczesnych „iluministów próżni” popularne były inspiracje religiami Dalekiego Wschodu, kabałą, teozofią, antropozofią Rudolfa Steinera,

\footnotetext{
2 Określenie Wasyla Kandinskiego; por. W. Kandinsky, Du spirituel dans l'art. Et dans la peinture en particulier, Paris 1979, s. 96.

${ }^{3}$ Por. treść hasła "Apofatyczna teologia”, [w:] Religia. Encyklopedia PWN, t. I, red. T. Gadacz, B. Milerski, Warszawa 2011, s. 278-279.
} 
czy szerzej - idee nowej duchowości (new age), to niewielu z nich stymulowały "przestarzałe” doktryny i motywy chrześcijańskie. Uznawano wręcz, że nie wpisują się one w awangardowy paradygmat sztuki.

W większości przypadków mistycy wzbraniają się przed opisem stanów swej duszy. Jeśli to czynią, to zazwyczaj z posłuszeństwa wobec woli Bożej oraz swych zwierzchników i przewodników duchowych. Szczególnie bezradni pozostają wobec widzeń intelektualnych, jakże różnych od dających się ująć słowem wizji zmysłowych i wyobrażeniowych ${ }^{4}$. Stanowią one bowiem - mówiąc słowami św. Jana od Krzyża - rodzaj poznania ponad pojęciami, „bez pośrednictwa zmysłów cielesnych zewnętrznych czy wewnętrznych, i przedstawiają się rozumowi sposobem nadprzyrodzonym jasno, wyraźnie i biernie" 5 .

„Uciekałam się do różnych porównań" - notuje święta Teresa z Avila „usiłując za ich pomocą jaśniej się wytłumaczyć, ale tego rodzaju widzenia z pewnością żadne podobieństwo, jak sądzę, dokładnie nie objaśni. Jest to bowiem sposób widzenia z rodzaju najwyższych" 6 .

Nie bez powodu więc uznano, że również w sztukach plastycznych bezpośrednie, realistyczne oddanie bezobrazowego i niewerbalnego ze swej istoty doświadczenia mistycznego, zwłaszcza jego "górnych pułapów”, jest nieosiągalne. Dopiero wyjście poza ramy tradycji ikonograficznej, a ściślej mówiąc - pojawienie się sztuki abstrakcyjnej, stworzyło nową jakość, uważaną za zdolną, by dotrzymać kroku świadectwom mistyków ${ }^{7}$. Choć nadal nie otworzyły się przed artystami możliwości zilustrowania doświadczenia wewnętrznego, sztuka pozwalała mu towarzyszyć, naprowadzała na trop "leżącej ponad rozumem ciemności"8.

Zgodnie $\mathrm{z}$ apofatycznym $\mathrm{w}$ swej genezie przeświadczeniem, iż w sztuce da się jedynie "przedstawić, że istnieje nieprzedstawialne", Jan Berdyszak najbardziej aktywnym i dominującym optycznie składnikiem swych realiza-

\footnotetext{
${ }^{4}$ Odwołuję się w tym miejscu do tradycyjnie trójstopniowego podziału wizji mistycznych na zmysłowe, wyobrażeniowe i intelektualne, obecnego już w pismach św. Augustyna, skodyfikowanego przez św. Jana od Krzyża i do dziś nie tracącego na aktualności; por. św. Jan od Krzyża, Droga na Górę Karmel, Księga II, 17,5; źródło: http://karmel.pl/klasyka/gora/index. php (dostęp: 17.10.2014).

${ }^{5}$ Ibidem, Księga II, 23,1

6 Św. Teresa z Àvila, Księga życia, rozdz. 28, 4-5, źródło:

http://www.karmelicibosi.pl/pdf/teresa/ksiegazycia.pdf (dostęp: 17.10.2014).

7 Por. A. Kramiszewska, Doświadczenie mistyczne w przekładzie na język sztuki. Wyzwania i pułapki na przykładzie ikonografii Trójcy Świętej, [w:] Fides Ex Visu. Okiem mistyka, red. A. Kramiszewska, Lublin 2012, s. 222.

8 Określenie Pseudo-Dionizego Areopagity z traktatu Teologia mistyczna, [w:] idem, Pisma teologiczne, tłum. M. Dzielska, Kraków 1997, s. 168.
} 
cji plastycznych, śmiało przekraczających granice tradycyjnych dyscyplin artystycznych, uczynił pustkę. Liczne wycięcia, prześwity, rozwarcia otwierają jego prace na przestrzeń, sprowadzając je niekiedy do roli obramowania - „przejścia ku całości”. Rzeczywistość, na którą pragnął nakierować uwagę odbiorcy, leży wszak poza obszarem widzialności i nie poddaje się kategoryzacji. Oto dlaczego św. Jan od Krzyża mówił o Bogu: todo - nada, czyli: wszystko - nic. Więcej o Nim nie da się powiedzieć. Mistycy wszystkich religii są co do tego zgodni. $Z$ tego też powodu sztuka niczego nam nie obrazuje ani niczego nie wyjaśnia „Widzieć coś i nie widzieć, patrząc, nie widzieć, patrząc, nie móc zobaczyć, lub widząc, nie móc patrzeć. Dostrzegać i nie móc określić - jest istotą całej sztuki" ${ }^{9}$ - zapisał J. Berdyszak w notatce sporządzonej w swym szkicowniku.

W pierwszych pracach z serii Miejsca rezerwowane (1973-76) funkcję takiej ramy pełnił romb płomienisty, zaczerpnięty przez z ikony Zbawiciel na Majestacie, gdzie oznacza "pełną ognia i światła naturę Boga"10 i mieści w sobie postać Chrystusa - wszechwładcy. W kolejnych realizacjach nawiązał artysta do kształtu mandorli ${ }^{11}$ oraz trójskrzydłowej nastawy ołtarzowej. $W$ jeszcze następnych zastosował figury euklidesowe: trójkąt, koło, kwadrat, tworzące w ikonie skomplikowaną metastrukturę o bogatej wymowie symbolicznej. W innym cyklu, nazwanym Facies (połowa lat 70-tych), rolę obramienia odgrywa zarys owalu głowy, inspirowany odciskiem twarzy Jezusa Chrystusa na tkaninie, powstałym „Boskim, niepojętym sposobem”. Z kolei w serii Requiem (1965-1970) swoistym mediatorem, "zarządzającym” napięciem między tym, co widoczne, a Niewyobrażalnym, jest forma tablic mojżeszowych.

W niektórych realizacjach tradycyjny kształt ramy nie ulega zaburzeniu, pozostając stosunkowo łatwy do identyfikacji. W innych zatraca jednak czytelność, rozwiera swe krawędzie, co sprzyja osmozie przestrzeni zewnętrznej i wewnętrznej i prowokuje do pytania o zasadność podziału na „święte" i „świeckie”. Rygoryzm kompozycji zostaje zakłócony przez skomplikowane przenikanie się figur, niespodziewanie płynny dukt niektórych krawędzi, wtargnięcie $\mathrm{w}$ nie kształtów obłych, organicznych. Artysta celowo plącze i zaciera ślady, by trzymać widza w niepewności i nie dopuścić do łatwych uogólnień i jednoznacznych interpretacji. Nie komunikuje nam przecież niczego konkretnego, lecz odsyła „przez nie - poza nie”, aż do granic wi-

9 J. Berdyszak, E. Olinkiewicz, Teatr, Wrocław 1996, s. 112.

10 W. Hryniewiczem OMI, Piękno i zbawienie. Kilka refleksji nad eschatologia ikony, [w:] Obraz $i$ kult. Materiaty z konferencji, , red. M. U. Mazurczak, J. Patyra, Lublin 1999, s. 154-155.

${ }^{11}$ Mandorla to rodzaj aureoli w kształcie migdała, tradycyjnie otaczającej postacie Jezusa i świętych. 
dzialności, by ujawniła się ich treść niewyczerpana i niewysłowiona. $\mathrm{W}$ istocie treść owa pozostaje tajemnicą, która ciągle się objawia, aby mimo to zawsze pozostać ukryta. Sens ostateczny jest zarazem granicą sensu' ${ }^{12}$.

Uświęcone tradycją motywy ikonograficzne i figury euklidesowe, „wypatroszone" z postaci świętych, lecz - o paradoksie! - zarazem je przywołujące, wskazują więc na fundamentalny wymiar doświadczenia Boskiej negatywności. Trudno się oprzeć skojarzeniom z, równie paradoksalną, treścią wiersza Paula Celana WMandorli:

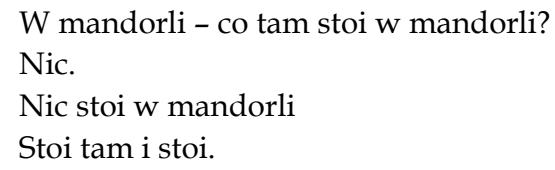

„Tam, gdzie Bóg zniknął, pojawia się nicość - konkluduje teolog Benedykt Welte - „i to, osobliwym sposobem, ponownie w wymiarach Boga”13.

Podobna ambiwalencja widoczna jest $\mathrm{w}$ malarskiej serii Belki krzyża $\mathrm{z}$ lat 1977-1988. Niektóre z Belek mają wygląd względnie konwencjonalny i zdają się odwoływać do tradycyjnej symboliki krzyża, skodyfikowanej w pierwszych wiekach chrześcijaństwa. Istnieją belki w kolorze czerwonym, fioletowym, niebieskim, które śmiało można wiązać ze stanem cierpienia lub $\mathrm{z}$ chwalebnym przejściem Chrystusa do wieczności. Wydrążone w nich szczeliny i pęknięcia przywołują myśl o ranach Skazańca, biegnące ukosem barwne smugi wywołują wizję ramion rozpiętych na krzyżu, a czarne poprzeczne linie są niczym sznury krępujące ręce w przegubie. Kształty i barwy innych prac cyklu zbijają nas jednak ze znanych tropów symbolicznych, a obecne w niech prześwity, wolne od treści martyrologicznej, wyznaczają rodzaj głębi niemożliwej do przeniknięcia. Miejsca puste, wnikając w prostokąt deski, odmykają ją na nieskończoność, ujawniają problem przejścia, przekraczania i zarazem niedopełnienia, stwarzającego możliwość dookreśleń. Wszystkie te obiekty, ograniczone do poziomu i pozbawione figury, odznaczają się charakterystyczną dla twórcy oszczędnością form wypowiedzi artystycznej i śladowym znaczeniem narracji. Malowane akrylami, pokryte werniksem, dzięki zmienności natężenia tej samej barwy stwarzają efekt wibracji, świetlistości i przestrzeni. Są belkami Syna Bożego, synonimem prawa jako bezprawia, przemocy i ludzkiej bezbronności, lecz zarazem

12 Por. G. van der Leeuw, Fenomenologia religii, tłum. J. Prokopiuk, Warszawa 1978, s. 721.

13 B. Welte, Das Licht des Nichts. Von der Möglichkeit neuer religiöser Erfahrung, cyt. za: F. Hunia, Sztuka w świetle nicości, [w:] Sztuka wobec prawdy, red. P. Kmieć, G. Sowiński, T.G. Wiktor, Nałęczów 1995, s. 97. 
„wszystkim innym”, czego nie da się już ująć werbalnie, co pozostaje nieskończenie różne od wyobrażeń ograniczonych kulturowo i religijnie. Bez względu bowiem na źródła inspiracji i rodowód przywołanych motywów, pochodzących z różnych obszarów kulturowych, w twórczości poznańskiego artysty: „Istotne nie jest dane, powiedziane, przedstawione czy uczynione, istotne ISTNIEJE pomiędzy, ISTOTNE zmierza ku mocy niewyrażalności" - jak zapisuje J. Berdyszak w 1977 roku14.

Można się zżymać na bez-bożną sztukę Jana Berdyszaka, na wybiórcze i, co więcej, jednostronne traktowanie symboli chrześcijańskich, pozostających w służbie "mocy nieobecności”. Podstawą obrazowania w sztuce Kościoła katolickiego i Cerkwi nie jest wszakże apofatyczna teza o niewidzialności i bezpostaciowości Boga, lecz prawda o Jego ucieleśnieniu i obrazowości, a także przeświadczenie o więzi między boskim archetypem a bytem świata. Ortodoksyjnego chrześcijanina drażnić też może obecność wykluczających się tradycji duchowych i motywów ikonograficznych o rozmaitej proweniencji religijnej, traktowanych przez twórcę jako równoważne, niekiedy wręcz wymienne, $\mathrm{w}$ dodatku otwarte na różne, a więc dowolne interpretacje $^{15}$. Nie da się jednak zaprzeczyć głęboko duchowej, a równocześnie dialogicznej istocie tej twórczości, pozostającej sztuką spotkania i rozmowy. Tworzonej przy tym z pełną świadomością, że w sposób najdoskonalszy człowiek realizuje się w spotkaniu z absolutnym, nieustannie obecnym "Ty" Boga. Gdy rozmyślam nad fenomenem dzieła Jana Berdyszaka - twórcy pełnego admiracji dla sztuki religijnej różnych narodów i epok, dla dociekań nad duchową esencją rzeczy - odnajduję w nim (fenomenie) pokrewieństwo z treścią poematu Czesława Miłosza Zapisane wczesnym rankiem (1967). Niech więc posłuży on za zwieńczenie tekstu i (jakże trafny) komentarz:

$$
\begin{aligned}
& {[\ldots] \text { Bóg sam }} \\
& \text { ojciec } \\
& \text { i uczyniciel } \\
& \text { wszystkiego co jest, }
\end{aligned}
$$

14 Tekst ze szkicownika artysty zamieszczony w katalogu wystawy: Jan Berdyszak, Galeria Sztuki Współczesnej Biura Wystaw Artystycznych i Muzeum Śląskiego w Katowicach, 1996, s. 62; wersaliki oryginalne.

15 „Wyznaczanie miejsc pustych" - pisze autor - „jest nie tylko ważną MOŻLIWOŚCIĄ ŚWIADOMOŚCI PUSTEGO, ale stawia człowieka w roli UŻYTKOWNIKA TYLKO WŁASNEJ WYOBRAŹNI - i tą drogą można dać początek możliwości odnajdywania wartości jednostkowych człowieka przez jednoczesność WYPEŁNIANIA I INTERPRETACJI. [...] Może do najważniejszych zadań sztuki obecnie należy wyznaczanie i «obrona» miejsca "pustego» dla mentalnej inicjatywy indywiduum ludzkiego [wersaliki oryginalne]"; J. Berdyszak, O obrazie, Muzeum Warmii i Mazur w Olsztynie, 1999, s. 46-47. 


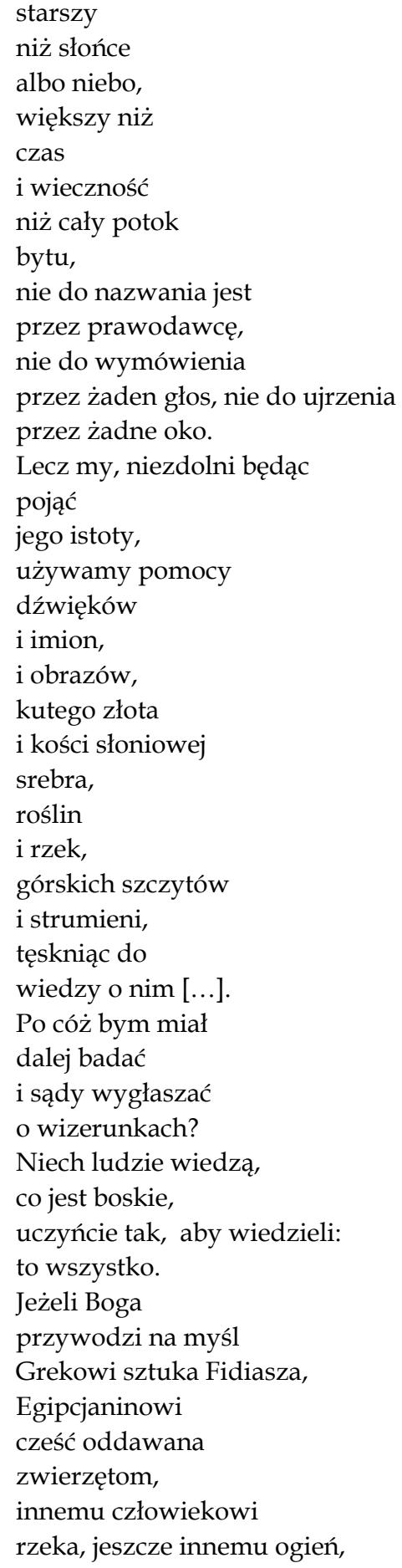


nie gniewa mnie

ich niezgoda;

byleby wiedzieli,

byleby kochali,

byleby pamiętali. [...] 